\title{
Virus-like particle production with yeast: ultrastructural and immunocytochemical insights into Pichia pastoris producing high levels of the Hepatitis B surface antigen
}

\author{
Heinrich Lünsdorf ${ }^{1}$, Chandrasekhar Gurramkonda ${ }^{2,3}$, Ahmad Adnan ${ }^{2,4}$, Navin Khanna ${ }^{3}$ and Ursula Rinas ${ }^{2,5^{*}}$
}

\begin{abstract}
Background: A protective immune response against Hepatitis B infection can be obtained through the administration of a single viral polypeptide, the Hepatitis B surface antigen (HBsAg). Thus, the Hepatitis B vaccine is generated through the utilization of recombinant DNA technology, preferentially by using yeast-based expression systems. However, the polypeptide needs to assemble into spherical particles, so-called virus-like particles (VLPs), to elicit the required protective immune response. So far, no clear evidence has been presented showing whether HBsAg assembles in vivo inside the yeast cell into VLPs or later in vitro during down-stream processing and purification.
\end{abstract}

Results: High level production of HBsAg was carried out with recombinant Pichia pastoris using the methanol inducible AOX1 expression system. The recombinant vaccine was isolated in form of VLPs after several downstream steps from detergent-treated cell lysates. Search for the intracellular localization of the antigen using electron microscopic studies in combination with immunogold labeling revealed the presence of HBsAg in an extended endoplasmic reticulum where it was found to assemble into defined multi-layered, lamellar structures. The distance between two layers was determined as $\sim 6 \mathrm{~nm}$ indicating that these lamellas represent monolayers of well-ordered HBsAg subunits. We did not find any evidence for the presence of VLPs within the endoplasmic reticulum or other parts of the yeast cell.

Conclusions: It is concluded that high level production and intrinsic slow HBSAg VLP assembly kinetics are leading to retention and accumulation of the antigen in the endoplasmic reticulum where it assembles at least partly into defined lamellar structures. Further transport of HBsAg to the Golgi apparatus is impaired thus leading to secretory pathway disfunction and the formation of an extended endoplasmic reticulum which bulges into irregular cloudshaped formations. As VLPS were not found within the cells it is concluded that the VLP assembly process must take place during down-stream processing after detergent-mediated disassembly of HBsAg lamellas and subsequent reassembly of HBsAg into spherical VLPS.

\section{Background}

Unlike many other vaccines against virus-caused diseases, a single viral polypeptide is sufficient to elicit a protecting immune response against Hepatitis B infection [1].

However, the polypeptide needs to assemble into spherical particles, so-called virus-like particles (VLPs),

\footnotetext{
* Correspondence: Ursula.Rinas@helmholtz-hzi.de

${ }^{2}$ Helmholtz Centre for Infection Research (SB), Braunschweig, Germany

Full list of author information is available at the end of the article
}

to initiate the required protective immune response [2]. In HBV infected individuals, viral surface proteins are produced in large excess in liver cells over the amount needed for virus assembly and are secreted as a mixture of spherical particles and tubular forms. Thus, in the serum of HBV infected patients, intact viruses (Dane particles) but also "empty" spherical particles and tubular forms consisting of the surface proteins of the Hepatitis $B$ virus are found $[3,4]$.

\section{Ciomed Central}


The first commercial vaccine was obtained from the plasma of asymptomatic virus carriers which contained HBsAg assembled into 22-nm spheres [1]. Safety issues as well as economical motives were driving the development of a vaccine utilizing modern DNA technology and, thus HBsAg became the first recombinant proteinbased vaccine, approved in 1986 by the Federal Drug Administration (USA), for human vaccination [5]. Initially, the yeast Saccharomayces cerevisiae was employed for commercial production of HBsAg from the viral gene encoding the 226 amino acids protein, as initial attempts to use $E$. coli based expression systems did not lead to the formation of immunoprotective material $[6,7]$ and mammalian based expression systems turned out to be too costly for vaccine production [1]. The human plasma and recombinant mammalian cell derived vaccines are glycosylated $[1,8]$. In contrast, yeast derived HBsAg is not glycosylated neither from $S$. cerevisiae [9] nor from the methylotrophic yeasts Hansenula polymorpha [10] and Pichia pastoris [11].

Expression of the native Hepatitis B virus $S$ gene in stably transfected mammalian cells leads to the secretion of HBsAg particles [12,13], however, attempts to achieve secretion of HBsAg in yeast have been unsuccessful. When the native viral gene is expressed in yeast, the protein is retained within the cells, but also efforts to enforce secretion in yeast by utilizing potent yeast or other eukaryotic secretion signals only lead to negligible amounts of secreted HBsAg with S. cerevisiae [8,14] or $P$. pastoris [15].

Despite wide-spread claims of intracellular VLP formation in $S$. cerevisiae $[9,16,17]$ and the methylotrophic yeasts $H$. polymorpha [10] and $P$. pastoris [11], no clear evidence has been presented so far that particle assembly occurs within the yeast cells. Electron microscopic proofs of VLP formation were always presented for purified material which was obtained from detergent-treated cell lysates after several down-stream processing steps $[9,10,18]$. In contrast to those claims of intracellular VLP assembly, it has been also speculated that VLP assembly from yeast produced material might occur during down-stream processing $[19,20]$. Thus, surprisingly, the question, if the HBsAg protein assembles in vivo inside the yeast cell into VLPs or later in vitro during down-stream processing, has no clear answer yet.

In this work we provide evidence that in Pichia pastoris, expression of the native viral HBsAg gene leads to translocation of the protein into the endoplasmic reticulum (ER) where it assembles, at least partly, into defined multi-layered lamellar structures. The HBsAg is retained within the ER or perinuclear space which bulges into cloud-shaped irregular formations. Despite intensive search we could not find any evidence for the presence of VLPs within the cells and thus conclude that VLP assembly must occur after cell breakage during subsequent down-stream processing.

\section{Results}

The production of HBsAg was carried out in high-cell density fed-batch cultures with recombinant $P$. pastoris GS115, using the methanol inducible $A O X 1$ expression system [18]. Cells were first grown in a batch procedure on defined medium with glycerol as carbon substrate. After depletion of glycerol, the production of HBsAg was induced by the addition of methanol to a final concentration of $6 \mathrm{~g} \mathrm{~L}^{-1}$. This methanol concentration was kept constant for the rest of the cultivation by continuous methanol feeding. During growth on methanol, intracellular accumulation of $\mathrm{HBsAg}$ was observed reaching a maximum concentration of $7 \mathrm{~g} \mathrm{~L}^{-1}$ which corresponds to approximately $70 \mathrm{mg}$ HBsAg per g cell dry mass, with 30 to $40 \%$ of it being "soluble" and competent for assembly into VLPs [18].

To determine the location and appearance of the Hepatitis B surface antigen in overproducing cells, electron microscopic studies in combination with immunogold labeling were carried out. Cells growing on glycerol and cells after induction of HBsAg synthesis through methanol feeding were first subjected to transmission electron microscopy for ultrastructural analysis (Figure $1 \mathrm{~A}$ and $1 \mathrm{~B}$, respectively). The ultrastructure of the cells changed substantially after exposure to methanol. In the cytosol of HBsAg-producing cells large irregular cloud-shaped areas of medium electron density became apparent (Figure 1B). These morphological features were absent in cells growing on glycerol (Figure 1A) and also absent in cells producing insulin precursor as secreted protein after exposure to methanol (Figure $1 C)$. Both cells producing either HBsAg or insulin precursor on methanol contained microbodies (peroxisomes) with internal crystal-like structures (Figures $1 \mathrm{C}$, 2 , and $3 \mathrm{~B}$ ). These peroxisomes are typical for methylotrophic yeast cells when growing on methanol $[21,22]$ and mainly contain enzymes necessary for the breakdown of carbon sources such as alcohols or fatty acids (e.g. alcohol oxidases, catalases, acetyl-CoA oxidases) [23-25].

However, a comprehensive search of electron micrographs of $P$. pastoris cells containing high levels of HBsAg for the presence of intracellular VLPs remained negative (Figures 1B, 2, 3, and 4). Circular, electron dense structures which might be misjudged as VLPs, found evenly distributed in the cytosol and also clustered on membranes, were identified as ribosomes (see also inserts in Figures $1 \mathrm{~A}-\mathrm{C}$ ). These "particles" were also visible in cells not exposed to methanol and thus in the absence of HBsAg production and in cells secreting insulin precursor during growth on methanol. 

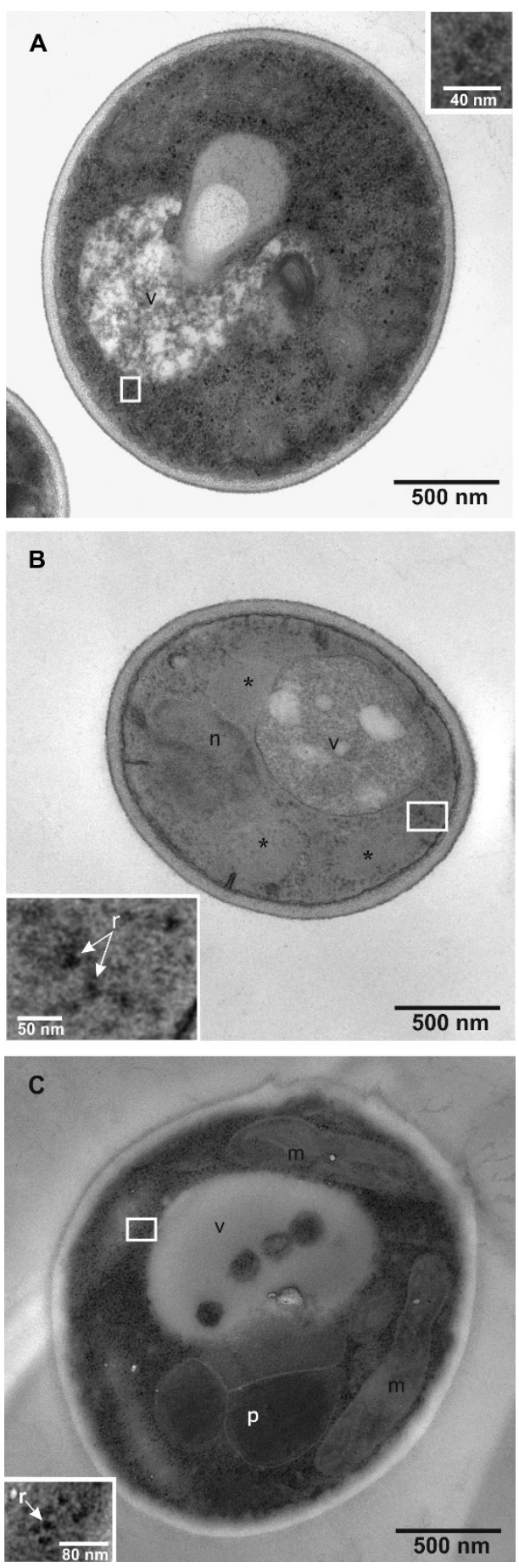

Figure 1 Images of recombinant $P$. pastoris growing on glycerol and methanol. Transmission electron microscopy of ultrathin sectioned cells of $P$. pastoris GS115 growing on (A) glycerol and (B) after $151 \mathrm{~h}$ growth on methanol for induction of HBsAg production. (C) Image of $P$. pastoris $X-33$ after $96 \mathrm{~h}$ growth on methanol for induction of secretory insulin precursor production [38]. Abbreviations: $n$, nucleus; $v$, vacuole; $m$, mitochondrion; $r$, ribosome; p, peroxisome; *, 'irregular cloud-shaped area'. The insets show close-ups of ribosomes from marked areas of respective images.
The ultrastructural appearance of HBsAg-producing cells appeared quite diverse, but all cells contained these large irregular cloud-shaped areas of medium electron density in addition to the other typical yeast organelles such as nuclei, mitochondria and vacuoles (Figures 1B, $2,3)$. These structures were consistently observed in cells which produced high levels of intracellular HBsAg but not in non-producing cells. Upon closer inspection a multi-layered, lamellar organization within these areas became apparent (Figure 3A1). For more clarity, an inverse fast Fourier transformation (iFFT) was carried out which revealed a defined spacing of app. $6 \mathrm{~nm}$ between the layers (Figure 3A2). These multi-layered lamellas were consistently observed in the HBsAg producing cells, but we could not find any indication for the presence of HBsAg VLPs $(22 \mathrm{~nm}$ diameter) which should be clearly visible at this magnification (Figure 3A1).

For comparison, close-ups and iFFTs of the typical internal crystal-like structures of peroxisomes reveal a line-spacing and thus a layer thickness of 10-11 nm (Figure 3B) characteristic of well-ordered protein layers composed of highly symmetrical building blocks [26,27]. In contrast to the crystal-like peroxisomal core regions with its straight layer lines (Figure 3B1 and 3B2), layers in the electron-dense cloud-shaped areas of the HBsAg producing cells appear bent and show distinct curvature of layer stacks (Figure 3A1 and 3A2) reflecting a different arrangement of the building block within the layer planes indicative of its potential to form circular vesicle structures.

Immunogold labeling of HBsAg producing cells with diluted polyclonal antibodies specific for HBsAg revealed selective labeling of the irregular shaped areas containing the multi-layered, lamellar structures strongly suggesting that the HBsAg protein assembles into these lamellas (Figure 4). Theoretical calculations of the size of a single HBsAg molecule $(26 \mathrm{kDa})$ indicate a diameter of $3 \mathrm{~nm}$ in case the molecule would adopt a spherical shape $[28,29]$. However, structural studies on purified HBsAg particles revealed that the smallest building blocks are HBsAg dimers in which the monomers are present in an extended conformation $[4,30]$. Thus, the interlayer spacing of $6 \mathrm{~nm}$ suggests that these lamellas represent HBsAg monolayers (Figures $3 \mathrm{~A}$ and 4C). Further close-up views also show that these structures are not dispersed in the cytosol but arise in the perinuclear space between the cytosolic and nucleic part of the nuclear double membrane leading to the formation of an extended ER (Figure 4D). These findings clearly show that the protein is translocated into the endoplasmic reticulum but is not further processed in the secretory pathway. High level production concomitant to ER retention leads to the formation of an 


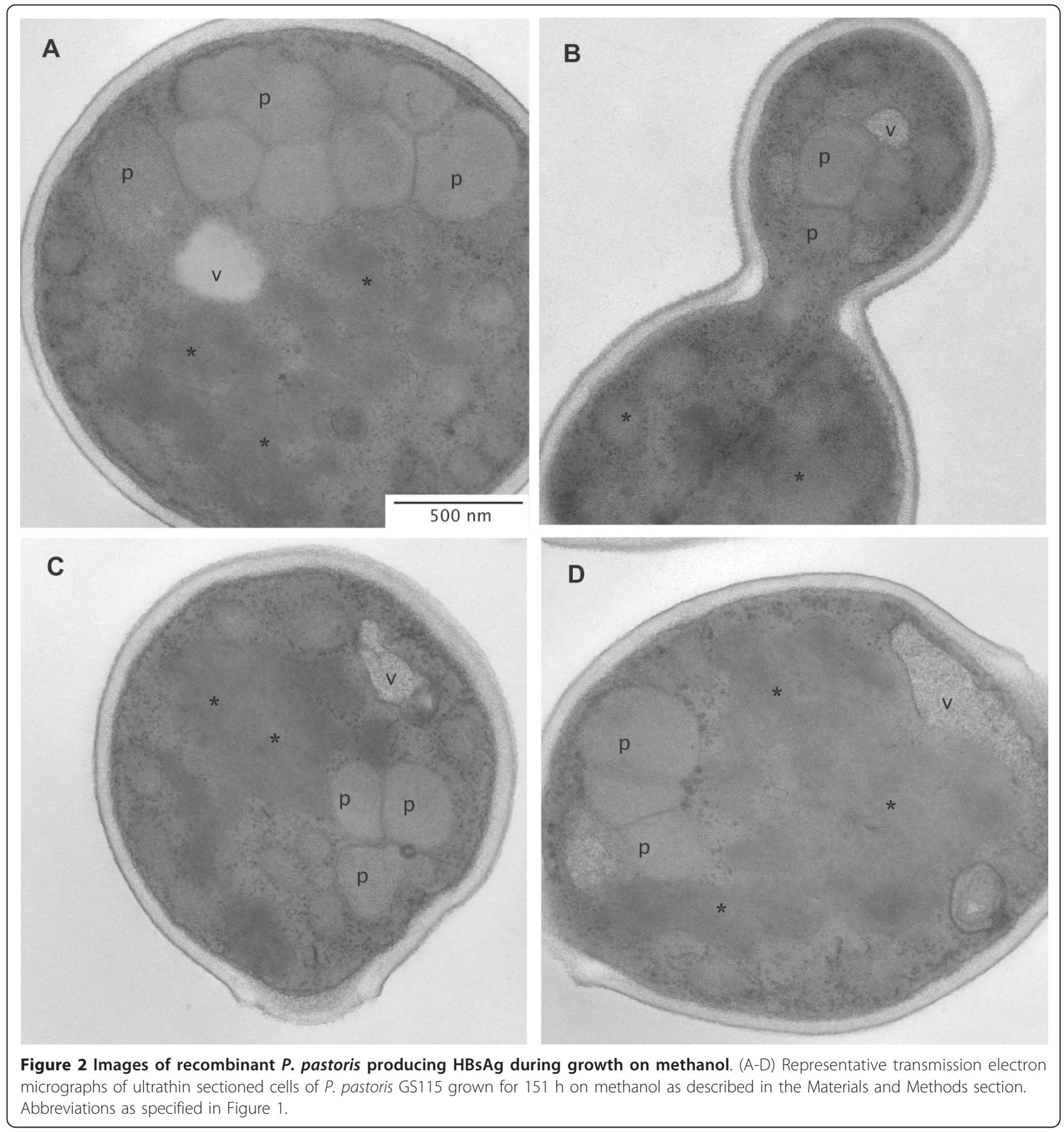

extended ER which bulges into cloud-shaped formations (see cartoon Figure 5). However, electron microscopic investigation of HBsAg purified from detergent treated cell lysates shows that the protein produced by $P$. pastoris can form VLPs (Figure 6). The absence of VLPs in the intact cells and the presence of VLPs in the final purified protein clearly show that the VLP assembly process does not occur in vivo but in vitro during downstream processing and purification.

\section{Discussion}

We could not find any indication that the assembly of the HBsAg polypeptide into VLPs occurs inside of $P$. pastoris. Instead, we provide evidence that the protein accumulates in an extended ER where it is found to assemble at least partly into multi-layered, lamellar structures. The layer spacing suggests the presence of HBsAg monolayers and clearly shows that HBsAg assembles into defined multimeric structures indicative 

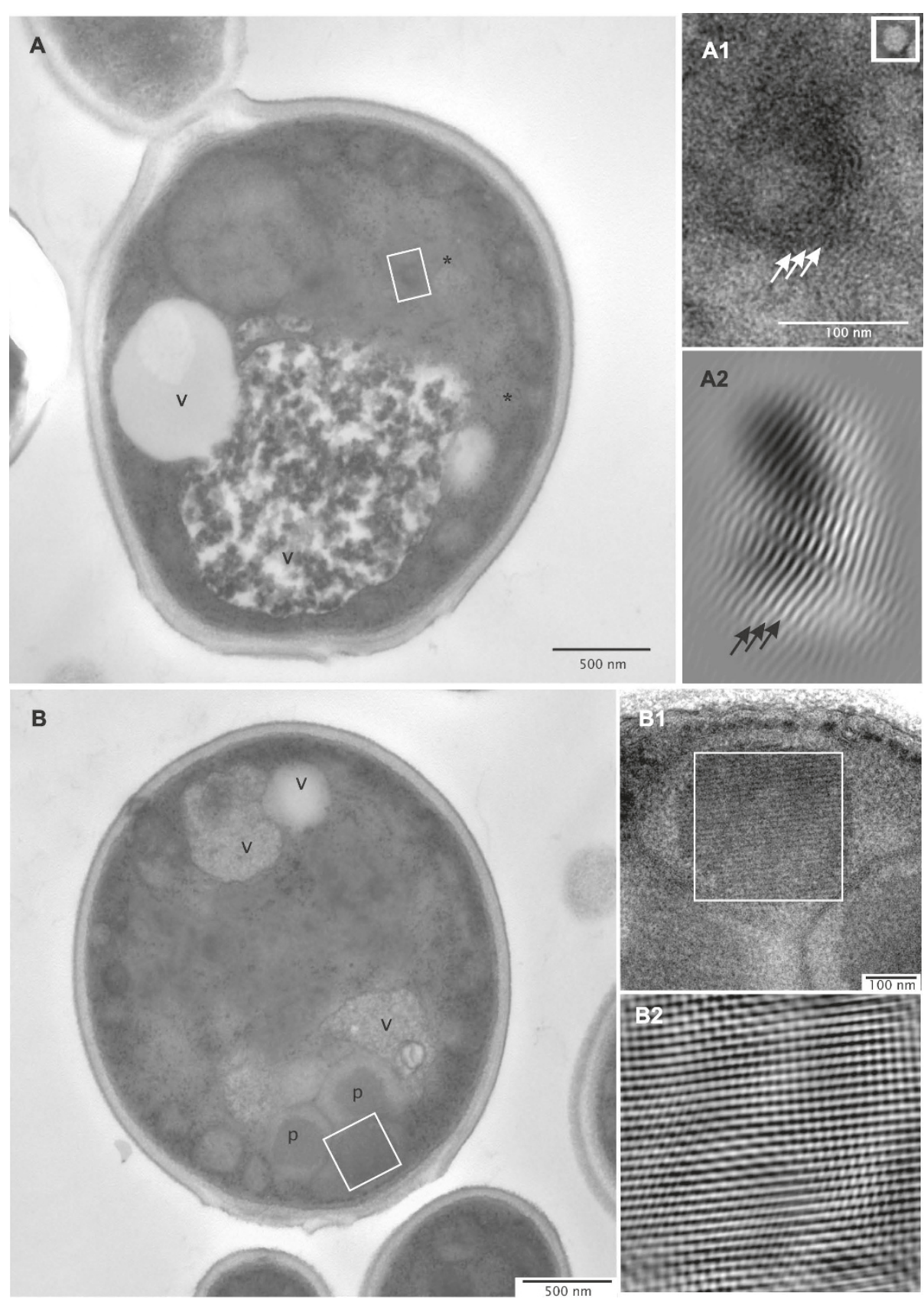

Figure 3 Close-up views of $P$. pastoris GS115 producing HBsAg. Transmission electron micrographs of single cells are shown in A and B. A1 is enlarged from the boxed area of A localized in the 'irregular cloud-shaped area' $\left.{ }^{*}\right)$, and the square-boxed insert of A1 shows a negatively stained reconstructed VLP with the same scale as in A1. A2 represents the corresponding inverse fast Fourier transformation (iFFT) of area A1. The $6 \mathrm{~nm}$ layer-spacing is indicated by arrows in A1 and A2. B1 is enlarged from boxed area in B; B2 represents the corresponding inverse fast Fourier transformation (iFFT) of area B1. Abbreviations as specified in Figure 1.

of a well-ordered monomer fold. The extended ER may also contain aggregated HBsAg as we did not see a comprehensive filling of the extended ER with these lamellar structures. However, it should also be noted that the visibility of these lamellar structures strongly depends on their parallel orientation relative to the electron beam. Translocation and retention of HBsAg in the ER of the yeast cell appears to be an intrinsic property of this very hydrophobic protein which has long stretches of connected hydrophobic amino acids.

The native viral HBsAg protein contains an $\mathrm{N}$-terminal secretion signal which directs this protein in mammalian cells to the ER without concomitant cleavage of the $\mathrm{N}$-terminal sequence [31]. This secretion signal is 


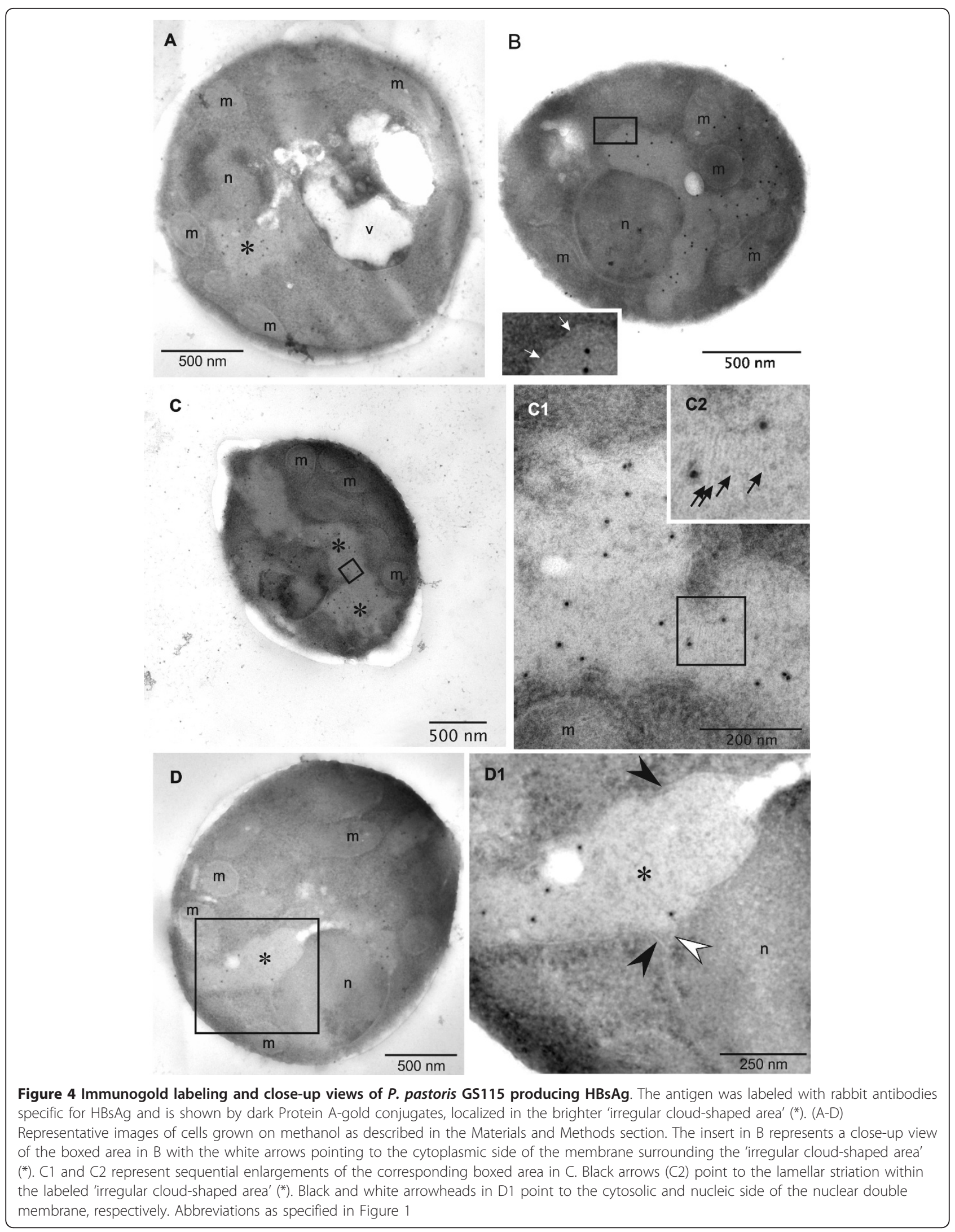


obviously also recognized by $P$. pastoris; the HBsAg is translocated into the lumen of the ER. In P. pastoris, however, the protein is retained in the ER and not further processed in the secretory pathway (Figure 5). In contrast, in mammalian cells which are stably transfected with the HBsAg gene, HBsAg particles are processed through the secretory pathway and secreted into the extracellular environment $[12,13]$. For mammalian cells, convincing evidence based on ultrastructural analysis has been presented which clearly shows that HBsAg assembles into VLPs in the ER [12]. However, it has also been shown that secretion of HBsAg from recombinant mammalian cells is a very slow process with a long half life $(\sim 5 \mathrm{~h})$ which is characteristic for HBsAg, as other viral envelope proteins are secreted with normal kinetics ( 30 min) [13]. These findings indicate an intrinsic slow assembly process of $\mathrm{HBsAg}$ into VLPs.

Compared to mammalian cells, protein synthesis rates are clearly faster in yeast cells in particular when the respective gene is under control of a strong promoter. When VLP assembly kinetics are slow compared to rates of protein synthesis and translocation into the ER, molecular crowding in the ER will interfere with the assembly of the protein into VLPs. This impairs further transport to the Golgi apparatus thus leading to secretory pathway dysfunction. Apparently, molecular crowding results in "mis-assembly" of $\mathrm{HBsAg}$ into the observed multi-lamellar structures in an extended ER which bulges into cloud-shaped irregular formations. Similarly, intracellular retention of HBsAg and failure of the protein to assemble into VLPs has also been reported from mammalian cells under conditions of elevated production [32]. Moreover, plant-cell derived HBsAg is not secreted but accumulates in the ER in tubular structures, differing substantially in appearance from the uniform size distribution of VLPs [33,34]. Tubular forms are not only formed in the ER of recombinant expression systems but are even found in the sera of chronic HBV-infected humans [3,4]. Thus, productive assembly pathways of folded HBsAg monomers seem to include the formation of VLPs but also the formation of tubular or even lamellar structures. Under conditions of intense production multi-lamellar structures will be favored as the HBsAg VLP assembly process is slow. However, our results indicate that these structures can be transformed into energetically more favorable VLPs under appropriate conditions. As we could not detect any VLPs within $P$. pastoris, we conclude that the VLP assembly process from yeast-derived HBsAg must take place during down-stream processing and purification.

\section{Methods}

\section{Strains and growth conditions}

The $P$. pastoris strain GS115 carrying 8-copies of the $H B s A g$ structural gene under the control of the $A O X 1$ promoter has been described before [35]. The $H B s A g$ gene was inserted in between the promoter and transcription termination regulatory elements without using yeast-derived secretory signals. Cells were grown on defined medium in a fed-batch procedure as described [18]. High-level production of HBsAg was initiated after

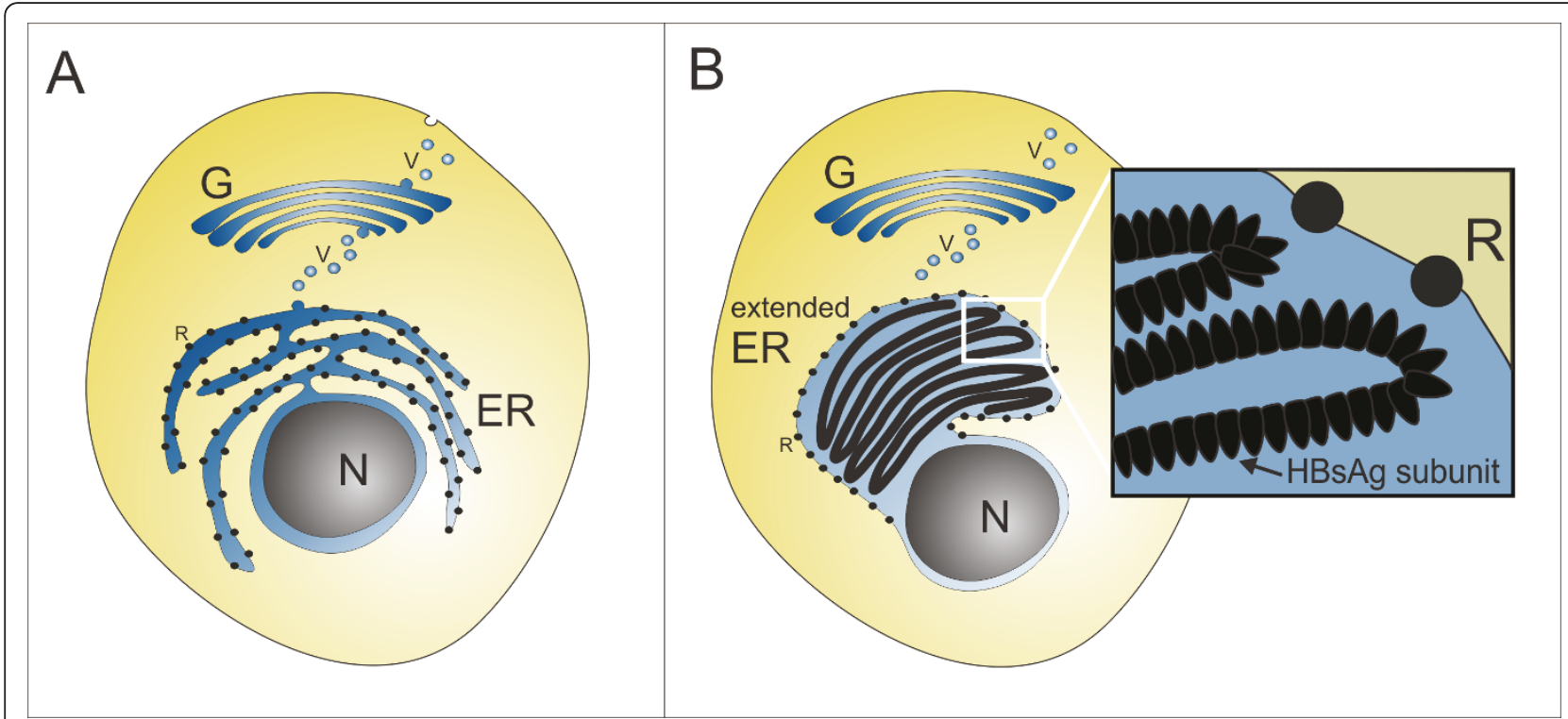

Figure 5 Conventional protein secretion and HBsAg production in P. pastoris. Cartoon displaying (A) the conventional secretory protein production pathway and (B) the HBsAg production and translocation pathway. N, nucleus; ER, endoplasmic reticulum; G, Golgi apparatus; V, secretory vesicle; R, ribosome; HBsAg, Hepatitis B surface antigen. 


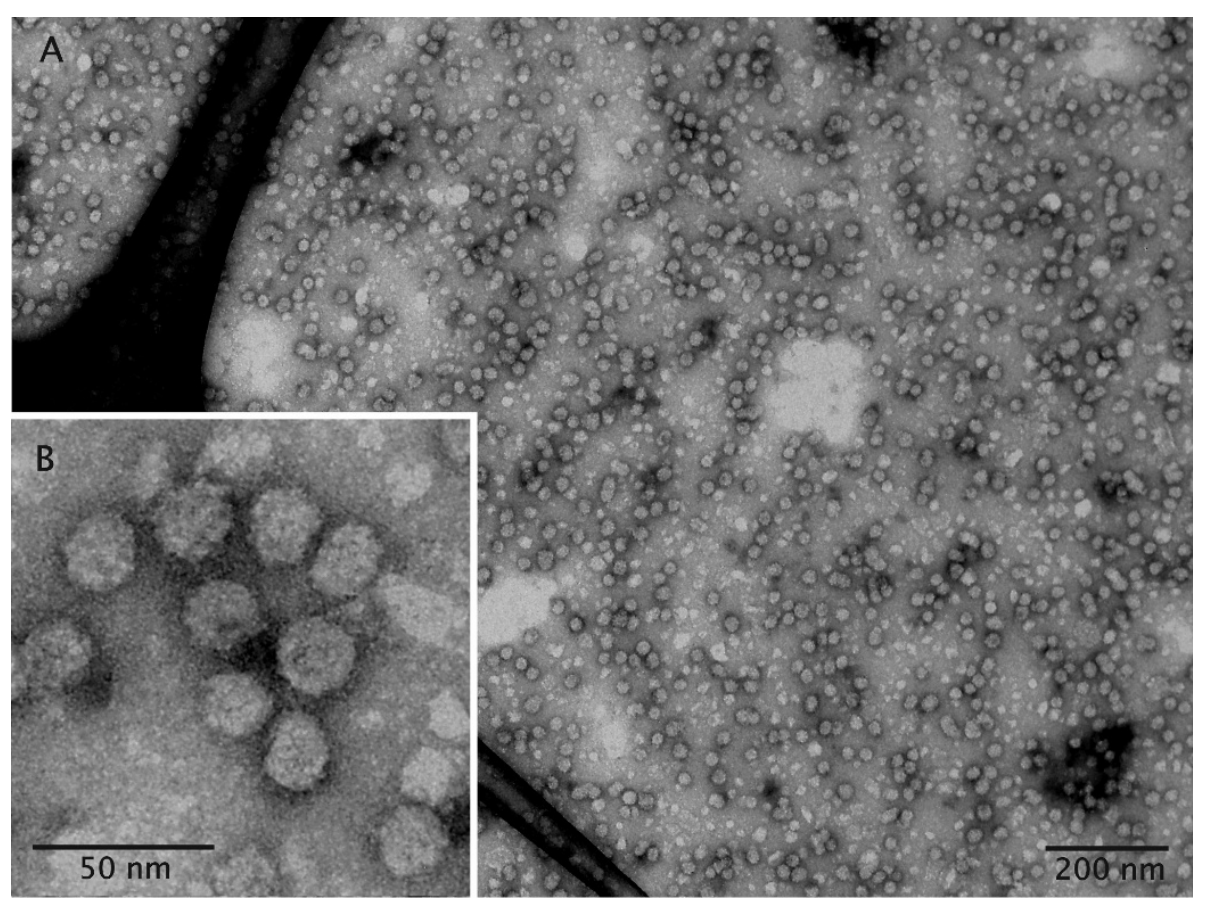

Figure 6 Purified VLPs composed of HBsAg. Transmission electron microscopy of negatively stained HBsAg VLPs after purification from detergent-treated cell lysate. Cells were collected after $170 \mathrm{~h}$ of growth on methanol and the HBsAg purified from the cell lysate as described in the Materials and Methods section. (A) Survey of negatively stained HBsAg VLPs and (B) close-up view revealing particles of uniform diameter $(\sim 22 \mathrm{~nm})$ and approximate icosahedral contour.

batch growth on glycerol through the addition of methanol to a final concentration of $6 \mathrm{~g} \mathrm{~L}^{-1}$. This methanol concentration was kept constant by continuous methanol feeding throughout the entire production phase. Process analytics and the determination of soluble and insoluble HBsAg produced by P. pastoris have been described previously [18].

\section{Purification of $\mathrm{HBsAg}$}

Cells from one liter culture broth were collected by centrifugation (Sorvall RC5BPlus, SLA 3000 rotor) at $4^{\circ} \mathrm{C}$ and 6,000 rpm for $15 \mathrm{~min}$, resuspended in $25 \mathrm{mmol} \mathrm{L}^{-1}$ phosphate buffer ( $\mathrm{pH} 8.0)$ and re-centrifuged. The cell pellet was resuspended in ice-cold lysis buffer $[25 \mathrm{mmol}$ $\mathrm{L}^{-1}$ phosphate buffer ( $\mathrm{pH} 8$ ), $5 \mathrm{mmol} \mathrm{L}{ }^{-1}$ EDTA, 0.6\% $(\mathrm{v} / \mathrm{v})$ Tween-20] and the pre-cooled cell suspension partly disrupted by high pressure homogenization (Gaulin Lab 60, APV Gaulin, Germany) with three cycles at 600 bar and $\sim 4^{\circ} \mathrm{C} . \mathrm{NaCl}\left(5 \mathrm{~mol} \mathrm{~L}^{-1}\right)$ was slowly added within $30 \mathrm{~min}$ to the cell lysate to a final concentration of $0.5 \mathrm{~mol} \mathrm{~L}^{-1}$ followed by the addition of polyethylene glycol $6000(50 \% \mathrm{w} / \mathrm{v})$ to a final concentration of $5 \%(\mathrm{w} /$ v). Precipitation was allowed to occur for $12-16 \mathrm{~h}$ at $4^{\circ} \mathrm{C}$ and the suspension was then clarified by centrifugation at $4^{\circ} \mathrm{C}$ and $6000 \mathrm{rpm}$ for $15 \mathrm{~min}$. The resultant supernatant was mixed with Aerosil 380 (Evonik, Hanau,
Germany) which was pre-equilibrated in $25 \mathrm{mmol} \mathrm{L}^{-1}$ sodium phosphate buffer ( $\mathrm{pH} 7.2$ ), $0.5 \mathrm{~mol} \mathrm{~L}^{-1} \mathrm{NaCl}$ ( $0.13 \mathrm{~g}$ of dry Aerosil 380 per gram of initial wet biomass). The suspension was stirred for $4 \mathrm{~h}$ at $\overline{4^{\circ} \mathrm{C}}$ and centrifuged at $4^{\circ} \mathrm{C}$ and $6000 \mathrm{rpm}$ for 15 minutes. The pellet was washed twice with $25 \mathrm{mmol} \mathrm{L}^{-1}$ phosphate buffer ( $\mathrm{pH}$ 7.2), and centrifuged as above. The resultant pellet was resuspended in $100 \mathrm{mmol} \mathrm{L}^{-1}$ sodium carbonate-bi-carbonate buffer ( $\mathrm{pH}$ 10.8), $1.2 \mathrm{~mol} \mathrm{~L}^{-1}$ urea and kept at $37^{\circ} \mathrm{C}$ for $12 \mathrm{~h}$ with stirring. This suspension was then centrifuged at $25^{\circ} \mathrm{C}$ and $10,000 \mathrm{rpm}$ for 60 minutes and the supernatant clarified by vacuum-filtration $(0.45$ $\mu \mathrm{m})$. The supernatant $\mathrm{pH}$ was adjusted to $\mathrm{pH} 8.0$ and proteins allowed to bind to the DEAE sepharose FF (Amersham Pharmacia Biotech, Sweden) pre-equilibrated with $100 \mathrm{mmol} \mathrm{L}^{-1}$ sodium carbonate-bi-carbonate buffer ( $\mathrm{pH}$ 8.0) using an XK column (Amersham Pharmacia Biotech, Sweden). After sample loading, the column was washed with $50 \mathrm{mmol} \mathrm{L}{ }^{-1}$ Tris- $\mathrm{HCl}(\mathrm{pH}$ 8.0) until the absorbance at $280 \mathrm{~nm}$ returned to baseline. Elution of bound HBsAg was carried out with 50 mmol L-1 Tris- $\mathrm{HCl}$ buffer ( $\mathrm{pH} 8$ ), $0.5 \mathrm{~mol} \mathrm{~L}^{-1} \mathrm{NaCl}$. Protein containing fractions (absorbance at $280 \mathrm{~nm}$ ) were pooled and mixed with caesium chloride (final concentration: $1.2 \mathrm{~g} \mathrm{~mL}^{-1} \mathrm{CsCl}$ ). This mixture was layered on top of an ultracentrifuge tube (T-865B tube, 
SORVALL) containing a $\mathrm{CsCl}$ solution with a density of $1.2 \mathrm{~g} \mathrm{~mL}^{-1}$ (density of HBsAg VLPs $\sim 1.18 \mathrm{~g} \mathrm{~mL}^{-1}$ ) and centrifuged at $22^{\circ} \mathrm{C}$ and $50,000 \mathrm{rpm}$ for $12 \mathrm{~h}$ (TV-865B rotor, SORVALL). The protein containing fractions of the ultraeluate were treated with $\mathrm{KSCN}$ at a final concentration of $1.2 \mathrm{~mol} \mathrm{~L}^{-1}$ and this mixture incubated at $37^{\circ} \mathrm{C}$ for $5 \mathrm{~h}$ in an orbital shaker (Multitron II, Infors AG, Germany), then dialyzed against phosphate buffered saline (PBS), sterile filtered, and stored as a concentrated solution of $500 \mu \mathrm{g} \mathrm{mL} \mathrm{m}^{-1}$ HBsAg VLPs.

\section{Electron microscopy}

\section{Fixation and embedding}

Samples from bioreactor cultivations were immediately fixed at ambient temperature in $2.5 \%(\mathrm{v} / \mathrm{v})$ glutardialdehyde in $20 \mathrm{mmol} \mathrm{L}^{-1}$ HEPES buffer (pH 7.1) for $30 \mathrm{~min}$. Cells were stored until embedment for several days at $4^{\circ} \mathrm{C}$. For ultrastructural analysis cells were immobilized in $1 \%$ $(\mathrm{w} / \mathrm{v})$ agar and further fixed in $1 \%(\mathrm{w} / \mathrm{v})$ osmiumtetroxide in $75 \mathrm{mmol} \mathrm{L}^{-1}$ cacodylate buffer (pH 7.2). Cells were dehydrated on ice in an ethanol series, stained with $1 \%$ $(\mathrm{w} / \mathrm{v})$ uranylacetate in $70 \%(\mathrm{v} / \mathrm{v})$ ethanol (for methacrylic LR-Gold embedding this staining step was omitted) and finally infiltrated with epoxy resin [36]. Cells were polymerized at $70^{\circ} \mathrm{C}$ for 8 hours. Ultrathin sections $(90 \mathrm{~nm})$ were cut with a diamond knife using an ultramicrotome (Leica, Wien, Austria), picked with Formvar-coated 300 mesh copper grids and poststained with uranyl acetate and lead citrate as described previously [37].

Cells used for immunocytochemical analysis were fixed in $0.5 \%(\mathrm{v} / \mathrm{v})$ glutardialdehyde, $3.5 \%(\mathrm{w} / \mathrm{v})$ paraformaldehyde in $20 \mathrm{mmol} \mathrm{L}^{-1}$ HEPES buffer ( $\mathrm{pH}$ 7) for 30 min at $20^{\circ} \mathrm{C}$ and kept at $4^{\circ} \mathrm{C}$ until further treatment for several days in a refrigerator. For embedding, cells were immobilized in $1 \%(\mathrm{w} / \mathrm{v})$ agar, dehydrated in an ethanol series and infiltrated in metacrylic LR-Gold resin. Polymerization was carried out with $0.1 \%(\mathrm{w} / \mathrm{v})$ benzil added at ambient temperature for 60 hours.

\section{Immunocytochemical treatment for antigen detection (Immunogold labeling)}

The ultrathin sections $(90 \mathrm{~nm})$ were picked with 300 mesh Ni-Butvar grids and layered on top of $30 \mu \mathrm{l} \mathrm{com-}$ mercially available rabbit polyclonal anti-HBsAg antibodies (Cat. No, BP 2029P, Acris Antibodies GmbH, Herford, Germany) in PBS (pH 7, 1:200 dilution) and incubated at $4^{\circ} \mathrm{C}$ overnight (sections on pure PBS buffer were used as blank control). The HBsAg antibody was used directly without immuno-affinity purification on HBsAg columns, however specificity against HBsAg was confirmed by Western blot using cell samples with and without HBsAg and by immunogold labeling of cells producing $\mathrm{HBsAg}$ and control cells not producing HBsAg (data not shown). After incubation with HBsAg antibodies, grids were washed 3 times in PBS for $10 \mathrm{~min}$ at ambient temperature. Labeling was done with protein G-gold $10 \mathrm{~nm}$ (Plano, Wetzlar, Germany), which binds specifically to the Fc part of IgG antibodies, diluted 1:200 with PEG-PBS $\left(0.5 \mathrm{mg} \mathrm{mL}^{-1}\right.$ polyethylene glycol 20,000 in PBS, pH 7) for 30 min at ambient temperature. Grids were washed twice for $5 \mathrm{~min}$ with $10 \mathrm{mmol}$ $\mathrm{L}^{-1}$ HEPES (pH 7), 0.03\% (v/v) Tween 20, followed by two additional washing steps for 5 min with $10 \mathrm{mmol} \mathrm{L^{- }}$ ${ }^{1}$ HEPES (pH 7) and one step with $10 \mathrm{mmol} \mathrm{L}^{-1}$ HEPES (pH 7), $1 \mathrm{mmol} \mathrm{L}^{-1}$ EDTA for $5 \mathrm{~min}$. The grids were then washed with $20 \mathrm{mmol} \mathrm{L}^{-1}$ Tris- $\mathrm{HCl}$ (pH 7), 5 mmol L ${ }^{-1}$ EDTA- $\mathrm{Na}_{4}$ for two minutes and stained with $2 \%(\mathrm{w} / \mathrm{v})$ uranyl acetate for $5 \mathrm{~min}$. Finally, the grids were jet-washed with water and the residual water was removed by filter paper and air-drying.

Ultrathin sections were analyzed with an energy-filtered transmission electron microscope (CEM 902, Zeiss, Oberkochen, Germany) in the elastic bright-field mode and images were captured with a $1 \times 1 \mathrm{k} \mathrm{CCD}$ camera (Proscan, Scheuring, Germany). Images of cells prepared for ultrastructural analysis or immunolabeling appear different as sample preparations followed different protocols.

\section{Image processing}

Ultrastructural analysis for noise reduction was carried out using fast Fourier transformation (FFT) and inverse fast Fourier transformation (iFFT) by CRISP software application (CRISP ver. 2.1; Calidris, Sollentuna, Sweden).

\section{Acknowledgements}

This work was supported by institutional core funds of the Helmholtz Centre for Infection Research and by an Indo-German program funded by DBT (India) and BMBF (Germany). Ahmad Adnan wishes to express his gratitude to the Higher Education Commission (HEC) of Pakistan for a post-doctoral fellowship. The skilful work of Inge Kristen on sample preparation for electron microscopy is gratefully acknowledged. The authors also wish to thank Thomas Ebensen for support during VLP purification by ultracentrifugation and also Andrew Perreth and Michael Schön for help during the first steps of down-stream processing.

\section{Author details}

${ }^{1}$ Helmholtz Centre for Infection Research (VAM), Braunschweig, Germany. ${ }^{2}$ Helmholtz Centre for Infection Research (SB), Braunschweig, Germany. ${ }^{3}$ International Centre for Genetic Engineering \& Biotechnology, New Delhi, India. ${ }^{4}$ Department of Chemistry, Government College University Lahore, Pakistan. ${ }^{5}$ Leibniz University of Hannover, Technical Chemistry - Life Science, Hannover, Germany.

\section{Authors' contributions}

$\mathrm{HL}$ carried out the electron microscopic studies and drafted the results section. CG purified the HBsAg. Both, CG and AA were involved in EM sample generation and NK in the initial outline of the project. UR conceived and directed the study and prepared the final manuscript. All authors read and approved the final manuscript.

\section{Competing interests}

The authors declare that they have no competing interests.

Received: 18 March 2011 Accepted: 26 June 2011

Published: 26 June 2011 


\section{References}

1. Stephenne J: Recombinant versus plasma-derived hepatitis B vaccines: issues of safety, immunogenicity and cost-effectiveness. Vaccine 1988, 6:299-303.

2. Cabral GA, Marciano-Cabral F, Funk GA, Sanchez Y, Hollinger FB, Melnick JL, et al: Cellular and humoral immunity in guinea pigs to two major polypeptides derived from hepatitis B surface antigen. J Gen Virol 1978, 38:339-350.

3. Neurath AR, Trepo C, Chen M, Prince AM: Identification of additional antigenic sites on Dane particles and the tubular forms of hepatitis $B$ surface antigen. J Gen Virol 1976, 30:277-285.

4. Short JM, Chen S, Roseman AM, Butler PJ, Crowther RA: Structure of hepatitis $B$ surface antigen from subviral tubes determined by electron cryomicroscopy. J Mol Biol 2009, 390:135-141.

5. Hilleman MR: Yeast recombinant hepatitis B vaccine. Infection 1987, 15:3-7.

6. Edman JC, Hallewell RA, Valenzuela P, Goodman HM, Rutter WJ: Synthesis of hepatitis B surface and core antigens in E. coli. Nature 1981, 291:503-506

7. Fujisawa $Y$, Ito $Y$, Sasada $R$, Ono $Y$, Igarashi $K$, Marumoto $R$, et al: Direct expression of hepatitis B surface antigen gene in E. coli. Nucleic Acids Res 1983, 11:3581-3591.

8. Kim EJ, Park YK, Lim HK, Park YC, Seo JH: Expression of hepatitis B surface antigen $S$ domain in recombinant Saccharomyces cerevisiae using GAL1 promoter. J Biotechnol 2009, 141:155-159.

9. Valenzuela P, Medina A, Rutter WJ, Ammerer G, Hall BD: Synthesis and assembly of hepatitis B virus surface antigen particles in yeast. Nature 1982, 298:347-350

10. Janowicz ZA, Melber K, Merckelbach A, Jacobs E, Harford N, Comberbach $M$, et al: Simultaneous expression of the $S$ and $L$ surface antigens of hepatitis $B$, and formation of mixed particles in the methylotrophic yeast, Hansenula polymorpha. Yeast 1991, 7:431-443.

11. Cregg JM, Tschopp JF, Stillman C, Siegel R, Akong M, Craig WS, et al: Highlevel expression and efficient assembly of hepatitis B surface antigen in the methylotrophic yeast, Pichia pastoris. Bio/Technology 1987, 5:479-485.

12. Patzer EJ, Nakamura GR, Simonsen CC, Levinson AD, Brands R: Intracellula assembly and packaging of hepatitis $B$ surface antigen particles occur in the endoplasmic reticulum. J Virol 1986, 58:884-892.

13. Patzer EJ, Nakamura GR, Yaffe A: Intracellular transport and secretion of hepatitis B surface antigen in mammalian cells. J Virol 1984, 51:346-353.

14. Kuroda S, Miyazaki T, Otaka S, Fujisawa Y: Saccharomyces cerevisiae can release hepatitis $B$ virus surface antigen $(\mathrm{HBsAg})$ particles into the medium by its secretory apparatus. Appl Microbiol Biotechnol 1993, 40:333-340.

15. Vassileva A, Chugh DA, Swaminathan S, Khanna N: Expression of hepatitis $B$ surface antigen in the methylotrophic yeast Pichia pastoris using the GAP promoter. J Biotechnol 2001, 88:21-35.

16. Kitano K, Nakao M, Itoh Y, Fujisawa Y: Recombinant hepatitis B virus surface antigen P31 accumulates as particles in Saccharomyces cerevisiae. Bio/Technology 1987, 5:281-283.

17. Biemans R, Thines D, Petre-Parent B, de Wilde M, Rutgers T, Cabezon T: Immunoelectron microscopic detection of the Hepatitis B virus major surface protein in dilated perinuclear membranes of yeast cells. DNA Cell Biol 1992, 11:621-626.

18. Gurramkonda C, Adnan A, Gäbel T, Lünsdorf H, Ross A, Nemani SK, et al: Simple high-cell density fed-batch technique for high-level recombinant protein production with Pichia pastoris: Application to intracellular production of Hepatitis B surface antigen. Microb Cell Fact 2009, 8:13.

19. Hitzeman RA, Chen CY, Hagie FE, Patzer EJ, Liu CC, Estell DA, et al: Expression of hepatitis B virus surface antigen in yeast. Nucleic Acids Res 1983, 11:2745-2763.

20. Wampler DE, Lehman ED, Boger J, McAleer WJ, Scolnick EM: Multiple chemical forms of hepatitis B surface antigen produced in yeast. Proc Natl Acad Sci USA 1985, 82:6830-6834.

21. Fukui S, Tanaka A, Kawamoto S, Yasuhara S, Teranishi Y, Osumi M: Ultrastructure of methanol-utilizing yeast cells: appearance of microbodies in relation to high catalase activity. J Bacterio/ 1975, 123:317-328.

22. van Dijken JP, Veenhuis M, Kreger-van Rij NJW, Harder W: Microbodies in methanol-assimilating yeasts. Arch Microbiol 1975, 102:41-44.
23. Gould SJ, McCollum D, Spong AP, Heyman JA, Subramani S: Development of the yeast Pichia pastoris as a model organism for a genetic and molecular analysis of peroxisome assembly. Yeast 1992, 8:613-628.

24. Liu H, Tan X, Veenhuis M, McCollum D, Cregg JM: An efficient screen for peroxisome-deficient mutants of Pichia pastoris. J Bacteriol 1992, 174:4943-4951.

25. Koller A, Spong AP, Luers GH, Subramani S: Analysis of the peroxisomal acyl-CoA oxidase gene product from Pichia pastoris and determination of its targeting signal. Yeast 1999, 15:1035-1044.

26. Vonck J, van Bruggen EF: Architecture of peroxisomal alcohol oxidase crystals from the methylotrophic yeast Hansenula polymorpha as deduced by electron microscopy. J Bacteriol 1992, 174:5391-5399.

27. Zhang H, Loovers HM, Xu LQ, Wang M, Rowling PJ, Itzhaki LS, et al: Alcohol oxidase (AOX1) from Pichia pastoris is a novel inhibitor of prion propagation and a potential ATPase. Mol Microbiol 2009, 71:702-716.

28. Wrighley NG: Electron micrographs of protein molecules: interconversion of size, shape and molecular weight made easy. Proc R Microsc Soc 1988, 23:299-302.

29. Zipper $P$, Kratky O: An X-ray small angle study of the bacteriophage fr and R17. Eur J Biochem 1971, 18:1-9.

30. Milhiet PE, Dosset P, Godefroy C, Le GC, Guigner JM, Larquet E, et al: Nanoscale topography of hepatitis $B$ antigen particles by atomic force microscopy. Biochimie 2011, 93:254-259.

31. Eble BE, Lingappa VR, Ganem D: Hepatitis B surface antigen: an unusual secreted protein initially synthesized as a transmembrane polypeptide. Mol Cell Biol 1986, 6:1454-1463.

32. Ma Z, Yi X, Zhang $Y$ : Enhanced intracellular accumulation of recombinant $\mathrm{HBsAg}$ in $\mathrm{CHO}$ cells by dimethyl sulfoxide. Process Biochem 2008, 43:690-695.

33. Smith ML, Mason HS, Shuler ML: Hepatitis B surface antigen (HBsAg) expression in plant cell culture: Kinetics of antigen accumulation in batch culture and its intracellular form. Biotechnol Bioeng 2002, 80:812-822.

34. Smith ML, Richter L, Arntzen CJ, Shuler ML, Mason HS: Structural characterization of plant-derived hepatitis B surface antigen employed in oral immunization studies. Vaccine 2003, 21:4011-4021.

35. Vassileva A, Chugh DA, Swaminathan S, Khanna N: Effect of copy number on the expression levels of hepatitis B surface antigen in the methylotrophic yeast Pichia pastoris. Protein Expr Purif 2001, 21:71-80.

36. Spurr AR: A low-viscosity epoxy resin embedding medium for electron microscopy. J Ultrastruct Res 1969, 26:31-43.

37. Reynolds EB: The use of lead citrate at high $\mathrm{pH}$ as an electron-opaque stain in electron microscopy. J Cell Biol 1963, 17:208-212.

38. Gurramkonda C, Polez S, Skoko N, Adnan A, Gäbel T, Chugh D, et al Application of simple fed-batch technique to high-level secretory production of insulin precursor using Pichia pastoris with subsequent purification and conversion to human insulin. Microb Cell Fact 2010, 9:31.

doi:10.1186/1475-2859-10-48

Cite this article as: Lünsdorf et al: Virus-like particle production with yeast: ultrastructural and immunocytochemical insights into Pichia pastoris producing high levels of the Hepatitis B surface antigen. Microbial Cell Factories 2011 10:48.

\section{Submit your next manuscript to BioMed Central and take full advantage of:}

- Convenient online submission

- Thorough peer review

- No space constraints or color figure charges

- Immediate publication on acceptance

- Inclusion in PubMed, CAS, Scopus and Google Scholar

- Research which is freely available for redistribution

Submit your manuscript at www.biomedcentral.com/submit
C Biomed Central 